\title{
Adsorption of bile salts from aqueous solution by plant fibre and cholestyramine
}

\author{
BY D. G. OAKENFULL AND DOROTHY E. FENWICK \\ CSIRO Division of Food Research, PO Box 52, NSW 2113 , Australia
}

(Received 14 March 1977 - Accepted I 2 April 1978)

\begin{abstract}
I. Adsorption of bile salts by dietary fibre is believed to promote their excretion and hence to reduce the serum cholesterol level in man and experimental animals.

2. We have tested a number of plant fibre fractions and other related materials for their ability to adsorb bile salts from aqueous solution. The 'insoluble' plant fractions were from 'dry grain' (a residue from brewing), apple, wheat bran, lucerne (Medicago sativa), soya beans, mung beans (Phaseolus mungo), chick peas (Cicer arietinum), rolled oats, spinach (Spinacia oleracea), sunflower seeds, sawdust and sheep faeces. The other materials were cholestyramine, pectin and lignins prepared from wheat bran and from sawdust.

3. Only cholestyramine and the fibre from lucerne, soya beans, mung beans, chick peas, spinach, and sunflower seeds adsorbed enough of either sodium cholate or sodium deoxycholate for adsorption to be detectable.

4. This result conflicts with a report that the lignin component of dietary fibre is responsible for adsorption of bile salts.

5. Adsorption of bile salts, when it occurs, may depend on the presence of saponins bound to the fibre.
\end{abstract}

Dietary fibre has been defined as 'that part of plant material taken in our diet which is resistant to digestion by secretions of the human gastrointestinal tract' (Trowell, 1972). It consists mainly of lignin and undigestible carbohydrates such as cellulose, hemicelluloses and pectins. A prevailing low-fibre diet has been blamed for some, at least, of the diseases associated with Western civilization, in particular ischaemic heart disease (Trowell, 1975). Feeding trials have shown that addition of fibre to the diet can lower the serum cholesterol level in both man and experimental animals. Plants and plant fractions which have this effect include lucerne (Medicago sativa) (Horlick, Cookson \& Federoff, 1967), oats (de Goot, Luyken \& Pikaar, 1963; Fisher \& Griminger, 1967), various beans (Mathur, Khan \& Sharma, I968; Devi \& Kurup, 1970), wheat straw (Moore, 1967), pectin (Keys, Grande \& Anderson, I96I; Jenkins, Leeds, Newton \& Cummings, 1975) and guar gum (Riccardi \& Fahrenbach, 1969; Jenkins et al. 1975).

A possible explanation for the effect of dietary fibre on the serum cholesterol level is that fibre adsorbs bile salts (Trowell, 1975). Bile salts are then excreted and must be replenished by metabolism of cholesterol in the liver (Heaton, 1972). Support for this explanation comes from experiments which have been claimed to show that bile salts are adsorbed from aqueous solution by plant fibre preparations (Eastwood \& Hamilton, 1968; Balmer \& Zilversmit, I974; Birkner \& Kern, 1974; Kritchevsky \& Story, 1974).

We set out to extend these adsorption studies by investigating the binding of bile salts to pectin but were unable to detect binding. Furthermore, we have been unable to detect adsorption of bile salts from aqueous solution by a wide range of plant fibre and related materials (in particular, lignins). However, experiments on adsorption by cholestyramine (an anion-exchange resin which strongly adsorbs bile salts and is used medicinally to control hypercholesterolaemia (Kuksis, I97I)) and fibre containing saponins, confirmed that our methods are capable of detecting adsorption of bile salts. 


\section{EXPERIMENTAL}

\section{Materials}

Pectin was commercial material (Sunkist Orange Co., Ontario, California, USA). Most of the other plant fibre were prepared by exhaustive washing of the finely chopped material, first with water, then with ethanol (Eastwood \& Hamilton, I968). Soya beans, mung beans (Phaseolus mungo) and chick peas (Acer arietinum) were also treated with pronase (Smith, Reynolds, Buckingham \& Back, 1974) to remove protein (after an initial wash with water and removal of the lipid with diethyl ether). Fibre was prepared from sheep faeces by treatment with detergent (Van Soest, 1963). The faeces $(20 \mathrm{~g})$ were heated at $100^{\circ}$ for $2 \mathrm{~h}$ on a water-bath with $100 \mathrm{ml}$ of a solution containing sodium dodecylsulphate ( $(0 \cdot \mathrm{I} \mathrm{M})$, disodium dihydrogen ethylenediaminetetraacetate $(0.05 \mathrm{M})$ and disodium phosphate $(0.032 \mathrm{M})$. The product was then centrifuged and the solid residue repeatedly washed with water.

Lignin ('Klason lignin') was prepared from some of the fibre samples by treatment with sulphuric acid $(720 \mathrm{~g} / \mathrm{kg})$. The method has been described in detail by Eastwood \& Hamilton (1968).

Cholestyramine was a gift from Bristol-Myers Co. Pty Ltd, Sydney.

Bile salts were used as received from Calbiochem, Carlingford, NSW, after their purity had been checked by thin-layer chromatography (Kirchner, 1967)

\section{Adsorption measurements}

Adsorption by solid fibre preparations was estimated from the change in bile salt concentration on exposure of the solution to the adsorbant. In a typical experiment five solutions were prepared containing different concentrations of bile salt (usually within the range I-5 mM; see Table I). Samples ( $0.5 \mathrm{~g})$ of dry fibre preparation were mixed with $20 \mathrm{ml}$ of each solution in stoppered conical flasks. These were held at $25^{\circ}$ for $2 \mathrm{~h}$ in a reciprocating shaker-bath fitted with a thermostat. Two flasks were included which contained bile salt solutions without fibre, for use as standards. Three different methods were used to estimate bile salt concentrations: two physical methods and a colorimetric method.

Conductance measurements were used in some of the experiments. This method is very precise but has the disadvantage that buffered solutions cannot be used because of the high background conductance of the buffer. Measurements were made with a Wayne-Kerr Universal bridge B224 (The Wayne Kerr Co. Ltd, Chessington, Surrey). The cell was fitted with platinized platinum electrodes and was of a type designed for use with solutions which have a tendency to froth (Shedlovsky, 1949). All solutions were maintained at $25^{\circ}\left( \pm 0.05^{\circ}\right)$.

The other physical method was measurement of density to a precision of $\pm \mathrm{I} \mu \mathrm{g} / \mathrm{ml}$, using an Anton Paar precision density meter (DMA 02c; Anton Paar K.G., Graz, Austria). The method can be used for buffered solutions but the precision depends on keeping the buffer concentration exactly the same for all solutions, including the standards. A single large batch of the buffer solution was therefore prepared for use as the solvent throughout each set of experiments.

The colorimetric method was substantially that described by Boyd, Eastwood \& MacLean (I966) (a modified Pettenkofer reaction). Bile salt solutions were volumetrically diluted (when necessary) so that a $100 \mu \mathrm{l}$ sample contained approximately $20 \mathrm{nmol}$ bile salt. To this was added $5 \mathrm{ml}$ sulphuric acid $(700 \mathrm{ml} / \mathrm{l})$ followed, after I min, with $\mathrm{I} \mathrm{ml}$ of a freshly prepared solution of furfural $(2 \cdot 3 \mathrm{~g} / 1)$. The solutions were thoroughly mixed after each addition. The extinction at $510 \mathrm{~nm}$ was measured after $80 \mathrm{~min}$. (It was found that this period of time was needed for complete development of the colour.) Test solutions were measured in duplicate; standards and blanks in quadruplicate. 
The precision of each method of concentration measurement was estimated by statistical analysis of results for twenty-four standard solutions of sodium cholate with concentrations ranging from $10 \mathrm{mM}$ to $\mathrm{I} \mathrm{mM}$. The results are summarized in Table 2 . They show that the colorimetric method is substantially less reliable for standard solutions than either of the two physical methods.

Adsorption by pectin (more correctly termed 'binding' since the adsorbant is itself in solution) was estimated by two methods: equilibrium dialysis and the effects of pectin on the ionic mobility of the bile salt anion. In the dialysis experiments, dialysis tubes containing pectin $(5 \mathrm{~g} / \mathrm{kg}: 20 \mathrm{ml})$ were placed in I mM-sodium cholate solution or water $(50 \mathrm{ml})$ in stoppered flasks and held at $25^{\circ}$ for 24,48 or $72 \mathrm{~h}$. The concentration of sodium cholate was well below the critical micelle concentration (Carey \& Small, 1972), thus avoiding the problem of slow equilibration which is encountered in dialysis of micellar solutions (Harrap \& O'Donnell, 1954). The concentration in the outer solution was measured by the three methods described. The time interval allowed for equilibration made no difference to the results. Buffer was added to those solutions for which the sodium cholate concentration was measured by colorimetry or density (see p. 300).

The effect of pectin on the ionic mobility of bile salt anions was estimated by comparing the electrical conductivity of solutions with and without pectin $(\mathrm{I} g / \mathrm{kg})$. Details are given along with the results in the following section.

\section{Buffer and $\mathrm{pH}$}

Solutions other than those used for conductance measurements contained equal concentrations $(0.02 \mathrm{M})$ of sodium dihydrogen phosphate and disodium hydrogen phosphate. The $\mathrm{pH}$ was checked after each adsorption experiment and found to be $6 \cdot 74 \pm 0.04$.

\section{Surface area measurements}

The external specific surface area of a number of fibre preparations was measured by a method substantially that of Giles and his co-workers (Giles \& Nakhwa, 1962; Giles \& Tolia, 1964; Giles, D'Silva \& Trivedi, 1970) as modified by Fleischfresser \& Freeland (1976). Samples $(0.2 \mathrm{~g})$ of fibre were dried at $110^{\circ}$ for $2 \mathrm{~h}$ and cooled in a desiccator. These were then equilibrated at $25^{\circ}$ with $5 \mathrm{ml}$ of a series of standard solutions of 4 -nitrophenol in dry $n$-hexane. The equilibrium concentration of 4-nitrophenol was measured spectrophotometrically. Adsorption of 4-nitrophenol corresponding to formation of a monolayer was estimated from the adsorption isotherm and the specific surface area of the fibre was calculated from the surface area covered by a 4 -nitrophenol molecule $\left(52.5 \times 10^{-20} \mathrm{~m}^{2}\right.$; Giles et al. 1970).

\section{RESULTS AND DISCUSSION}

Interaction of sodium cholate and sodium deoxycholate with pectin

The effect of pectin on the mobility of cholate ions was estimated from measurements of electrical conductance. The ionic mobility is proportional to the equivalent conductance (Robinson \& Stokes, 1955). The effect of pectin on the equivalent conductance of sodium cholate solutions is shown in Fig. $r$. The values obtained for solutions of sodium cholate containing pectin $(\mathrm{I} \mathrm{g} / \mathrm{kg}$ ) are indistinguishable from those for solutions of sodium cholate in water alone. Thus pectin has no effect on the mobility of the cholate ion and there is no interaction between the two solutes. Similar results were obtained for sodium deoxycholate. The two bile salts are not therefore bound by pectin in solution.

This result was confirmed for sodium cholate by equilibrium dialysis. The equilibrium concentration of sodium cholate was always that to be expected if there were no binding to pectin $(0.714 \mathrm{~mm})$. Experiments in which pectin was dialysed against only water or buffer 


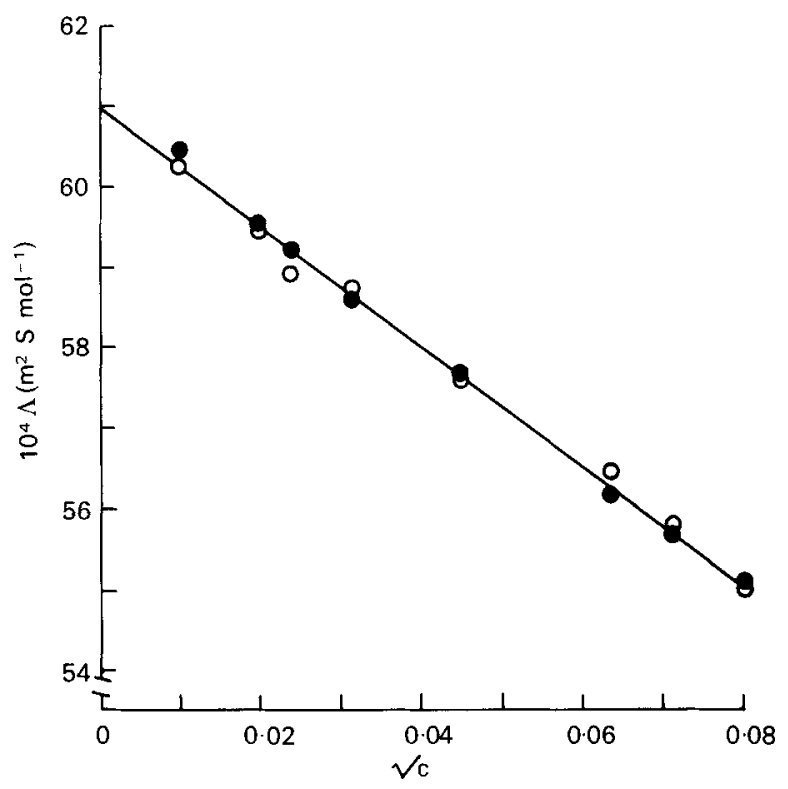

Fig. I. Equivalent conductance $\left(\Lambda ; \mathrm{m}^{2} \mathrm{~S} \mathrm{~mol}{ }^{-1}\right)$ of sodium cholate at $25^{\circ} v$. the square root of the molar concentration $(\sqrt{ } \mathrm{c})$ : results obtained in $(\circlearrowleft)$, pure water; $(O)$ pectin $(\mathrm{I} g / \mathrm{kg})$.

solutions showed that nothing passed through the membrane to interfere with the estimation of sodium cholate concentration.

Pectin is not a well characterized substance. The process of extracting it from citrus fruits involves considerable breakdown of the original material (Joslyn, I962). It is therefore possible that bile salts might be adsorbed by pectin in the state in which it occurs in the cell walls of plants even though they are not bound by soluble pectin. However, we could detect no adsorption of sodium cholate or sodium deoxycholate by the fibre extracted from lemon albedo (Citrus limon L. Burm. f). (Lemon albedo contains approximately $340 \mathrm{~g}$ pectin $/ \mathrm{kg}$ (Kefford \& Chandler, 1970). These results are included in Table I.

\section{Adsorption of sodium cholate and sodium deoxycholate by solid fibre preparations}

In Table I we have listed the sources of fibre and the results of the adsorption measurements. The results are expressed in terms of the maximum amount of bile salt found to be adsorbed per $\mathrm{g}$ dry fibre within the experimental range of bile salt concentrations (usually $\mathrm{I}-5 \mathrm{mM}$ ). When no adsorption could be detected an upper limit was calculated from the estimated standard error of the concentration measurements (see Table 2).

These results suggest that plant fibre fractions in general do not have the ability to adsorb sodium cholate or sodium deoxycholate. We could detect no significant adsorption by fibre prepared from 'dry grain' (a residue from brewing), apple, sawdust, wheat bran, or rolled oats. Also, we could detect no adsorption by the various preparations of lignin.

This was a surprising result because at least four independent reports have appeared claiming that these or similar materials adsorb bile salts from aqueous solution (Eastwood \& Hamilton, 1968; Balmer \& Zilversmit, 1974; Birkner \& Kern, 1974; Kritchevsky \& Story, 1974; Story \& Kritchevsky, 1976). In particular, Eastwood \& Hamilton (I968) suggested that the lignin component of the fibre was responsible for adsorption of bile salts. (They found higher levels of adsorption by lignin prepared from their fibre than by the 
Table I. Maximum observed adsorption of bile salts by fibre ( $\mu$ mol $/ \mathrm{g}$ fibre) at $25^{\circ}$

(The bile salt concentration range was $1-5 \mathrm{~mm}$, unless otherwise indicated)

\begin{tabular}{|c|c|c|c|c|c|c|}
\hline \multirow{2}{*}{$\begin{array}{c}\text { Method of estimation } \\
\text { Source of fibre }\end{array}$} & \multicolumn{3}{|c|}{ Sodium cholate } & \multicolumn{3}{|c|}{ Sodium deoxycholate } \\
\hline & $\begin{array}{l}\text { Colori- } \\
\text { metric* }\end{array}$ & Density* & $\begin{array}{c}\text { Con- } \\
\text { ductance } \dagger\end{array}$ & $\begin{array}{l}\text { Colori- } \\
\text { metric* }\end{array}$ & Density* & $\begin{array}{c}\text { Con- } \\
\text { ductance }\end{array}$ \\
\hline $\begin{array}{l}\text { Lemon albedo (Citrus } \\
\text { limon) }\end{array}$ & $<0.2$ & $<0.03$ & $<0.01$ & $<0.2$ & $<0.03$ & $<0.01$ \\
\hline ‘Dry grain’ $\ddagger$ & $\begin{array}{l}<0.2 \\
(10.4)\end{array}$ & $<0.03$ & $<0.01$ & $<0.2$ & $<0.03$ & $<0.01$ \\
\hline Apple (Granny Smith) $\ddagger$ & $\begin{array}{l}<0.2 \\
(5.7)\end{array}$ & $<0.03$ & $<0.0 I$ & $<0.2$ & $<0.03$ & $<0.01$ \\
\hline Sawdust (Oregon pine) $\ddagger$ & $\begin{array}{l}<0.2 \\
(15 \cdot 0)\end{array}$ & $<0.03$ & $<0.01$ & $<0.2$ & $<0.03$ & $<0.01$ \\
\hline Wheat bran & $<0.2$ & $<0.03$ & - & $<0.2$ & $<0.03$ & - \\
\hline $\begin{array}{l}\text { Lucerne (Medicago } \\
\text { sativa)§ }\end{array}$ & $\begin{array}{r}17 \cdot 2 \\
(422)\end{array}$ & $17 \cdot 6$ & $17 \cdot 4$ & 25.7 & 24.9 & 24.9 \\
\hline Extracted lucerne\| & $<0.2$ & $<0.03$ & $<0.01$ & $<0.2$ & $<0.03$ & $<0.01$ \\
\hline Rolled oats & $<0.2$ & $<0.03$ & - & $<0.2$ & $<0.03$ & - \\
\hline Soya beans & II $\cdot 3$ & 9.8 & - & 18.5 & $18 \cdot 9$ & - \\
\hline Extracted soya beans $\|$ & $x \cdot 2$ & 0.6 & - & $2 \cdot 7$ & $2 \cdot 5$ & - \\
\hline $\begin{array}{l}\text { Mung beans } \\
\text { (Phaseolus mungo) }\end{array}$ & $5 \cdot 3$ & $4 \cdot 9$ & $4 \cdot 9$ & 6.8 & $6 \cdot 4$ & $6 \cdot 1$ \\
\hline Extracted mung beans $\|$ & $\mathrm{I} \cdot 2$ & $I \cdot 7$ & $\mathrm{I} \cdot 7$ & $2 \cdot 8$ & 2.5 & $2 \cdot 7$ \\
\hline $\begin{array}{l}\text { Chick peas (Cicer } \\
\text { arietinum) }\end{array}$ & $5 \cdot 7$ & $5 \cdot 2$ & $5 \cdot \mathrm{I}$ & $10 \cdot 2$ & $8 \cdot 5$ & $8 \cdot 6$ \\
\hline Extracted chick peas $\|$ & $<0.2$ & 0.1 & $0 . I$ & $<0.2$ & 0.3 & $0 . I$ \\
\hline $\begin{array}{l}\text { Spinach (Spinacia } \\
\text { oleracea) }\end{array}$ & $2 \cdot 0$ & $2 \cdot 0$ & $I \cdot 9$ & $7 \cdot 9$ & $7 \cdot 0$ & $6 \cdot 9$ \\
\hline $\begin{array}{l}\text { Sunflower seeds } \\
\text { Lignin from: }\end{array}$ & $2 \cdot I$ & $I \cdot 5$ & $1 \cdot 7$ & $2 \cdot 8$ & 3.4 & $3 \cdot 5$ \\
\hline Sawdust & $<0.2$ & $<0.03$ & $<0.0$ I & $<0.2$ & $<0.03$ & $<0.01$ \\
\hline Wheat bran & $<0.2$ & $<0.03$ & - & $<0.2$ & $<0.03$ & - \\
\hline Sheep faeces: & & & & & & \\
\hline Wheaten hay diet & $<0.2$ & $<0.03$ & - & $<0.2$ & $<0.03$ & - \\
\hline Ryegrass diet & $<0.2$ & $<0.03$ & - & $<0.2$ & $<0.03$ & - \\
\hline Cholestyramine§ & $\begin{array}{l}570 \\
(2040)\end{array}$ & - & - & - & - & - \\
\hline $\begin{array}{l}\text { ‘Dry grain’+ lucerne- } \\
\text { saponin } \|\end{array}$ & 34 & $2 \cdot 9$ & $2 \cdot 8$ & - & - & - \\
\hline Bran + lucerne-saponin** & 37 & - & $4 \mathrm{I}$ & - & - & - \\
\hline
\end{tabular}

original material.) We are unable to account for the discrepancy between our results and the earlier work.

Eastwood \& Hamilton (I968) provide excellent experimental details and we followed their methods for preparing fibre. Inevitably there must be differences between what is nominally the same biological material but from different sources. Eastwood \& Hamilton's (1968) 'dry grain', for example, was from a whisky distillery whereas the source for this study was a brewery. It is possible that the materials used in this study were sufficiently 
Table 2. Statistical analysis of the precision of the methods for estimating bile salt concentrations

\begin{tabular}{|c|c|c|}
\hline Method of estimation & $\begin{array}{l}\text { Coefficient of } \\
\text { variation of } \\
\text { twenty-four } \\
\text { observations }\end{array}$ & $\begin{array}{l}\text { Standard error } \\
\text { for analyses } \\
\text { carried out } \\
\text { in duplicate* }\end{array}$ \\
\hline $\begin{array}{l}\text { Colorimetry } \\
\text { Conductance } \\
\text { Density }\end{array}$ & $\begin{array}{l} \pm 9.76 \\
\pm 0.99 \\
\pm 2.26\end{array}$ & $\begin{array}{l} \pm 6.9 \\
\pm 0.70 \\
\pm 1.60\end{array}$ \\
\hline
\end{tabular}

Table 3. External specific surface areas measured by adsorption of 4-nitrophenol from $\mathrm{n}$-hexane at $25^{\circ}$

$\begin{array}{lc}\text { Material } & \begin{array}{c}\text { Specific } \\ \text { surface area } \\ \left(\mathrm{m}^{2} / \mathrm{kg}\right)\end{array} \\ \text { Lucerne (Medicago sativa) fibre } & 531 \\ \text { Extracted lucerne fibre* } & 540 \\ \text { Wheat bran fibre } & 720 \\ \text { Mung bean (Phaseolus mungo) fibre } & 716 \\ \text { Extracted mung bean fibre* } & 716 \\ \text { Lignin from wheat bran } & 579 \\ \text { Rayon } \dagger & 243 \\ \text { had been extracted with ethanol-water }(80: 100, \mathrm{v} / \mathrm{v}) \text {. (See p. 305.) } \\ \text { \& Tolia (1964). }\end{array}$

different to account for the different results. The lignin samples also were prepared by the method described by Eastwood \& Hamilton (1968) in which the material is treated with sulphuric acid. This treatment introduces another potential source of variation since sulphuric acid alters the structure of the original lignin; the product is usually referred to as 'Klason lignin' (Harkin, 1973). Therefore adsorption of sodium cholate and sodium deoxycholate by fibre prepared from sheep faeces was also investigated. This material contains a high proportion of lignin (approximately $35 \%$; Harkin, 1973) prepared under milder conditions than treatment with sulphuric acid. Again, we could detect no adsorption of bile salts (see Table I).

The possibility was considered that the adsorption reported by others may have been due to contamination of the solutions with metal ions. (Metal ions could conceivably chelate to both fibre and bile salt, forming a bridge between the two). However, no significant effect on the adsorption of sodium cholate by 'dry grain' by the ions of calcium, barium or magnesium ( $0.0 \mathrm{I} \mathrm{M}$ ) could be detected. (In these experiments the phosphate buffer was replaced by $0.01 \mathrm{M}$-imidazole, half-neutralized, at $\mathrm{pH} 6.99$.)

It is possible that those fibre preparations which did not significantly adsorb bile salts did not do so because they have anomalously low surface areas. Therefore the external specific surface area of the fibre preparations from lucerne, wheat bran and mung beans and also that of lignin prepared from wheat bran was measured. The results are shown in Table 3 . There is no significant difference between the specific surface areas of fibre preparations which adsorb bile salts (lucerne and mung bean) and those which do not (wheat bran and lignin). Lucerne fibre, which is the strongest adsorbant, has the smallest specific 


\section{Adsorption of bile salts by plant fibre}

surface area and all the preparations have surface areas greater than that reported for rayon. It was therefore concluded that the present results were not due to surface area effects .

The following considerations indicated that the results described in Table I were reliable and that fibre in general does not adsorb bile salts: ( 1 ) the results are reproducible; (2) three different methods for measuring bile salt concentrations gave concordant results; (3) adsorption by cholestyramine and some plant fibre preparations was clearly evident.

The lack of demonstrable adsorption by wheat bran agrees with its observed lack of effect on serum cholesterol levels in man (Truswell \& Kay, 1976). However, there was no detectable adsorption by fibre from oats whereas oats have been shown to lower the serum cholesterol level in man (de Goot et al. 1963).

\section{A possible role of saponins in bile salt adsorption}

Those plant fibre preparations which adsorbed bile salts (Table I) were from lucerne, soya beans, mung beans, chick peas, spinach and sunflower seeds. They differ from the other materials listed in Table I, with the exception of oats, in that they contain saponins (Basu \& Rastogi, 1967; Birk, 1969). Saponins are amphiphilic substances which consist of a hydrophobic steroid or triterpene group joined to a sugar (a hexose, pentose or saccharic acid; Birk, 1969). Consequently they are strongly surface active and may induce binding of bile salts to polysaccharides. The bile acids associate with other hydrophobic molecules by hydrophobic interaction (Oakenfull \& Fenwick, 1977) and many, but not all, saponins form insoluble molecular compounds with cholesterol and other hydroxy steroids (Birk, 1969). Thus there is likely to be a strong hydrophobic interaction between bile salt molecules and the steroid or triterpene part of a saponin (although not necessarily giving an insoluble molecular compound). It is therefore possible that saponins remaining with the fibre are responsible for the adsorption of bile salts.

The following evidence supports this idea: (I) the ability of these fibre preparations to adsorb sodium cholate disappeared or was greatly reduced when they were exhaustively extracted with ethanol-water $(80: 100, \mathrm{v} / \mathrm{v})$ in a soxhlet apparatus. (This is a standard procedure for extracting saponins from plant materials (Bondi, Birk \& Gestetner, 1973). Results for fibre subjected to this further extraction procedure are included in Table 1 . The further extraction had no effect on the specific surface area of the fibre from lucerne and mung beans (see Table 3); (2) fibre from 'dry grain' adsorbed sodium cholate when a crude extract of lucerne saponin was added to the sodium cholate solutions at a concentration of $10 \mathrm{~g} / \mathrm{l}$. The amount adsorbed, though, was considerably less than by lucerne fibre under the same conditions (this result is included in Table 1 ). Also, a preparation of wheat bran treated with lucerne saponins adsurbed sodium cholate more strongly than any of the materials listed in Table I except cholestyramine. In this experiment, saponin was extracted from $5 \mathrm{~g}$ lucerne chaff with ethanol-water $(80: \mathrm{I00}, \mathrm{v} / \mathrm{v} ; 200 \mathrm{ml})$. Bran fibre $(5 \mathrm{~g})$ was then added to the extract and the mixture was evaporated to dryness. Maximum adsorption by this material was $4 \mathrm{I} \mu \mathrm{mol} / \mathrm{g}$ compared with $17.2 \mu \mathrm{mol} / \mathrm{g}$ for lucerne fibre (see Table $\mathrm{I}$ ); it is likely that some of the saponin is removed from the lucerne during preparation of the fibre and this would account for the lower adsorption of sodium cholate than that found for adsorption by bran with saponin.

Loss of saponin during preparation may also explain why the fibre from oats did not adsorb bile salts. The saponin content of oats is relatively low (Maizel, Bunkardt \& Mitchell, 1964) and most of it may have been lost during the preparation of the fibre. 

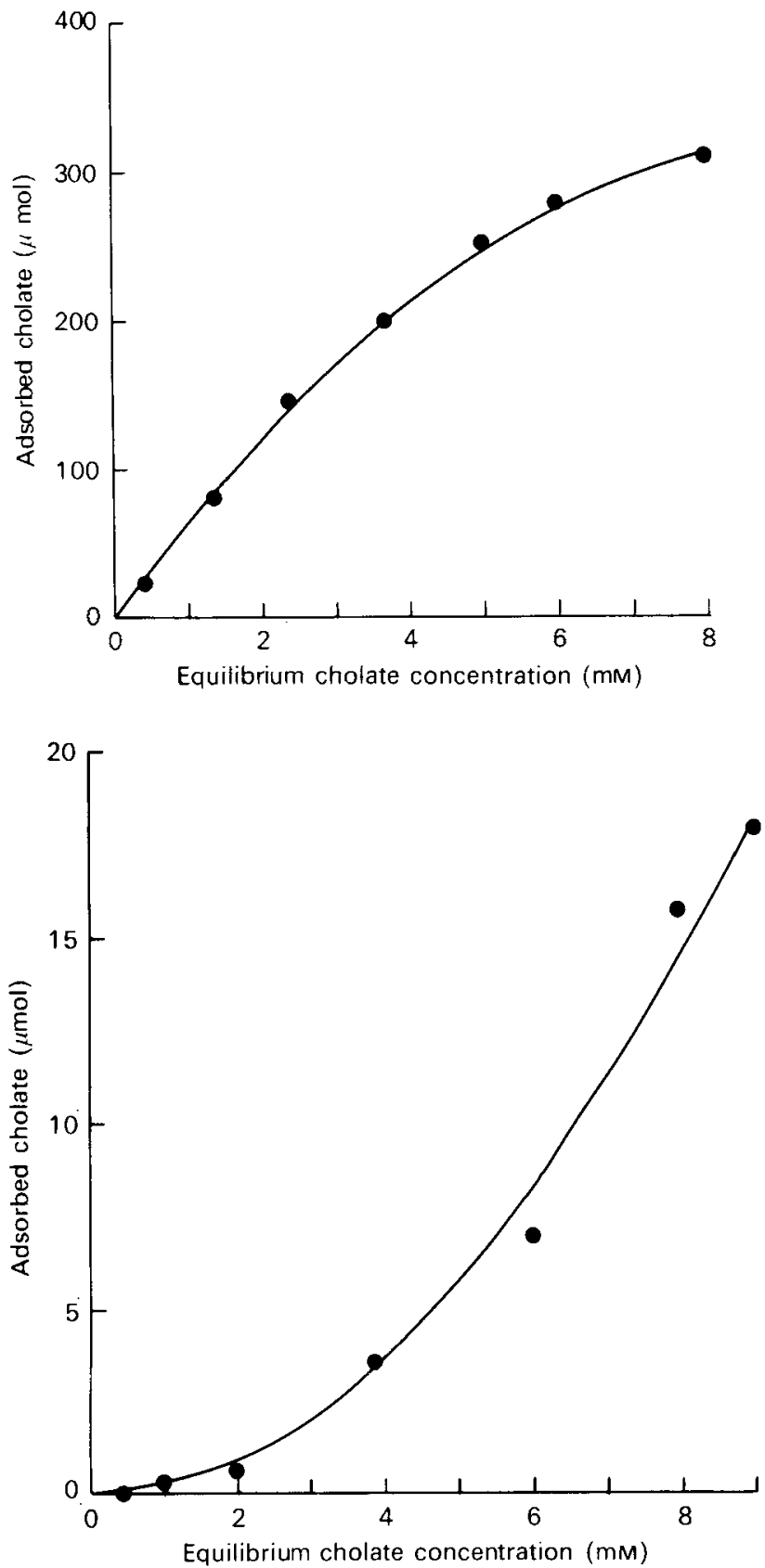

Fig. 2. Isotherms at $25^{\circ}$ for the adsorption of sodium cholate by $0.5 \mathrm{~g}(\mathrm{a})$ cholestyramine (top)and $(b)$ lucerne (Medicago sativa) fibre. The concentration of sodium cholate is the final, equilibrium, concentration after adsorption. The curves are theoretical and based on the Langmuir adsorption model (see p. 307). 


\section{Adsorption isotherms}

The effect of increasing concentration of sodium cholate on its adsorption by lucerne fibre and by cholestyramine at $25^{\circ}$ is shown in Fig. 2. The two processes are clearly different.

In the instance of cholestyramine the results can be described by an adsorption isotherm analogous to that of Langmuir (or BET type I; Brunauer, 1945) for adsorption from the gas phase. Treating the process in the usual way, as a quasi-chemical equilibrium (Ponec, Knor \& Černy, I974):

sodium cholate + cholestyramine $\rightleftharpoons K$ sodium cholate bound to cholestyramine, gives the relationship:

$$
c / A=c / n+\mathrm{I} / n K
$$

in which $c$ is the concentration of free sodium cholate, $A$ is the no. of mol sodium cholate adsorbed (/g polymer), $n$ is the no. of binding sites (mol/g polymer) and $K$ is the association constant. Rearrangement of the results shown in Fig. $2(a)$ in this form gives the predicted linear relationship between $c / A$ and $c$. The correlation coefficient was 0.9982 and the values of $n$ and $K$ are given in Table 4 .

The results for lucerne fibre (Fig. $2(b)$ ) have the appearance of a BET type $V$ adsorption isotherm (Brunauer, 1945). This form of isotherm is characteristic of adsorption onto a surface consisting of fine pores or capillaries (Brunauer, Deming, Deming \& Teller, 1940). The specific surface area of lucerne fibre, though, is similar to that of the other materials studied (Table 3).

Adsorption to the other fibre preparations followed the Langmuir or BET type I isotherm. It is possible that the surface structure of these materials may have been more altered than that of lucerne fibre by the procedure used to prepare them. Values of $K$ and $n$ for adsorption of sodium cholate are listed in Table 4 . It is interesting that $K$ remains approximately the same for all types of fibre and that it is $n$ which varies and determines the amount of bile salt adsorbed.

\section{Conclusions}

The only plant fibres which were found to adsorb bile salts were those prepared from plants containing saponins. Newman, Kummerow \& Scott (1958) reported that dietary saponins lower the liver cholesterol level, but not that in the serum, of chickens and suggested that the same effect might occur in man. It has been reported that an extract of horse chestnuts (Aesculus hippocastanum), which are particularly rich in saponins, inhibits and reduces the development of atherosclerosis in rabbits and rats (Mikhailova, Nikolova \& Stoyanov, 1965). Also, lucerne saponins have been shown to prevent hypercholesterolaemia in monkeys (Malinkow, McLaughlin, Kohler \& Livingston, I977).

Saponins are widely distributed in the plant kingdom and have been identified in approximately 500 species (Basu \& Rastogi, 1967; Bondi et al. 1973). Table 5 lists those sources of dietary fibre which have been shown to lower the serum cholesterol level in man or experimental animals and indicates which of these plants contain saponins. The saponincontaining plants make up half the total.

Saponins remain within the gastrointestinal tract and are not adsorbed into the blood stream (Birk, I969). Thus it is possible that dietary saponins may contribute to the effect of the fibre with which they are eaten on the excretion of bile salts and consequently on the serum cholesterol level.

This suggestion is supported by a recent report of the effect of soya-bean textured-protein on serum cholesterol levels in man (Sirtori, Agradi, Conti, Mantero \& Gatti, 1977). This experiment was with a group of twenty patients with type II hyperlipoproteinaemia. They 
Table 4. Values of association constant $(K ; l / m o l)$ and no. of binding sites $(n ; \mu m o l / g)$ for adsorption of sodium cholate by fibre preparations at $25^{\circ}$

\begin{tabular}{lrc}
\multicolumn{1}{c}{ Source of fibre } & \multicolumn{1}{c}{$\boldsymbol{K}$} & $n$ \\
Cholestyramine & 7700 & 92 \\
Soya beans & 400 & 95 \\
Chick peas (Cicer arietinum) & 160 & 97 \\
Mung beans (Phastolus mungo) & 160 & 88 \\
Spinach (Spinacia oleracea) & 77 & 70 \\
Sunflower seeds & 45 & 100
\end{tabular}

Table 5. Plants or plant products reported to lower serum cholesterol levels

\begin{tabular}{|c|c|c|c|}
\hline Plant material & $\begin{array}{c}\text { Saponin } \\
\text { content } \\
(\mathrm{g} / \mathrm{kg} \\
\text { dry } \\
\text { weight })\end{array}$ & $\begin{array}{l}\text { Ex- } \\
\text { perimental } \\
\text { animal }\end{array}$ & Reference \\
\hline Lucerne (Medicago sativa) & $20-30^{*}$ & Rabbit & (Horlick et al. 1967) \\
\hline $\begin{array}{l}\text { Oats } \\
\text { Rolled oats }\end{array}$ & $0.15 \dagger$ & $\left\{\begin{array}{l}\text { Chicken } \\
\text { Man }\end{array}\right.$ & $\begin{array}{l}\text { (Fisher \& Griminger, 1967) } \\
\text { (de Goot et al. 1963) }\end{array}$ \\
\hline $\begin{array}{l}\text { Chick pea (Cicer arietinum) } \\
\text { Black gram (Phaseolus mungo)§ }\end{array}$ & $2-3 \ddagger$ & $\left\{\begin{array}{l}\text { Rat } \\
\text { Man }\end{array}\right.$ & (Devi \& Kurup, 1970) \\
\hline \multicolumn{3}{|l|}{ Green gram (Phaseolus radiatus)§ } & \multirow{3}{*}{ (Mathur et al. 1968) } \\
\hline Horse gram (Dolichus biflorus) & oll & & \\
\hline Red gram (Cajanus cajan) & oll & & \\
\hline Wheat straw & o\| & Rabbit & \multirow[b]{2}{*}{ (Moore, 1967) } \\
\hline Rice bran & o\|l & Rat & \\
\hline Pectin & o & Man & $\left\{\begin{array}{l}\text { (Keys et al. } 1961 ; \\
\text { Jenkins } \text { et al. } 1975)\end{array}\right.$ \\
\hline Guar gum & o & $\left\{\begin{array}{l}\text { Rat } \\
\text { Man }\end{array}\right.$ & $\begin{array}{l}\text { (Riccardi et al. 1969) } \\
\text { (Jenkins et al. 1975) }\end{array}$ \\
\hline Carageenan & 0 & Rat & (Riccardi et al. 1969) \\
\hline Soya-bean textured-protein & $c 2$ & Man & (Sirtori et al. 1977) \\
\hline
\end{tabular}

were fed on two low-lipid diets. One with animal protein; one with soya-bean texturedprotein. Both diets had almost the same fibre content. The diet with soya-bean texturedprotein lowered the patient's mean serum cholesterol level by $21 \%$ after 3 weeks whereas the diet with animal protein had only a small effect. This effect is unlikely to be simply due to a substitution of vegetable for animal protein (Hermus, Stasse-Wolthuis \& Hantvast, 1977). Soya beans, though, contain approximately $5 \mathrm{~g} / \mathrm{kg}$ dry weight of saponins which remains with the protein during processing (Smith \& Circle, 1972). We estimated the saponin content of a sample of soya-bean textured-protein by the foam volume method (O'Dell, Regam \& Beach, 1959). It contained 4.8 times as much saponin as the same weight of whole soya beans.

It is suggested that saponins induce adsorption of bile salts to dietary fibre. Thus the presence of saponins as a dietary component may enhance the effect of dietary fibre on serum cholesterol levels. 


\section{REFERENCES}

Balmer, J. \& Zilversmit, D. B. (1974). J. Nutr. 104, 1319.

Basu, N. \& Rastogi, R. P. (I967). Phytochemistry 6, 1249.

Birk, Y. (1969). In Toxic Constituents of Plant Foodstuffs, pp. 169-21 10. New York: Academic Press.

Birkner, J. H. \& Kern, F. (1974). Gastroenterology 67, 237.

Bondi, A., Birk, Y. \& Gestetner, B. (I973). In Chemistry and Biochemistry of Herbage, vol. I, pp. 5I I-528

[G. W. Butler and R. W. Bailey, editors]. London: Academic Press.

Boyd, G. S., Eastwood, M. A. \& MacLean, N. (I966). J. Lipid Res. 7, 83.

Brunauer, S. (1945). The Adsorption of Gases and Vapors, vol. 1. Princeton: Princeton University Press.

Brunauer, S., Deming, L. S., Deming, W. E. \& Teller, E. (1940). J. Am. Chem. Soc. 62, 1723.

Carey, M. C. \& Small, D. M. (1972). Archs intern. Med. 130, 506.

de Goot, A. P., Luyken, R. \& Pikaar, N. A. (1963). Lancet ii, 303.

Devi, K. S. \& Kurup, P. A. (1970). Atherosclerosis r1, 479.

Eastwood, M. A. \& Hamilton, D. (1968). Biochim biophys. Acta 152, 165.

Fisher, H. \& Griminger, P. (1967). Proc. Soc. exp. Biol. Med. 126, 108.

Fleischfresser, B. E. \& Freeland, G. N. (1976). J. appl. Polymer. Sci. 20, 3453.

Giles, C. H., D'Silva, A. P. \& Trivedi, A. S. (1970). J. appl. Chem. 20, 37.

Giles, C. H. \& Nakhwa, S. N. (1962). J. appl. Chem. 12, 266.

Giles, C. H. \& Tolia, A. H. (1964). J. appl. Chem. 14, 186.

Harkin, J. M. (1973). In Chemistry and Biochemistry of Herbage, vol. I, pp. 323-373 [G. W. Butler and R. W. Bailey, editors]. London: Academic Press.

Harrap, B. S. \& O'Donnell, I. J. (1954). J. phys, Chem. 58, 1097.

Heaton, K. W. (1972). Bile Salts in Health and Disease, p. 129. Edinburgh: Churchill-Livingstone.

Hermus, R. J. J., Stasse-Wolthuis, M. \& Hantvast, J. G. A. J. (1977). Lancet i, 905.

Horlick, L., Cookson, F. B. \& Federoff, S. (1967). Circulation 35-36, I I.

Jenkins, D. J. A., Leeds, A. R., Newton, C. \& Cummings, J. H. (1975). Lancet i, I 16.

Joslyn, M. A. (1962). Adv. Fd Res. r, I.

Kefford, J. F. \& Chandler, B. V. (1970). The Chemical Constituents of Citrus Fruits. New York: Academic Press.

Keys, A., Grande, F., \& Anderson, J. T. (1961). Proc. Soc. exp. Biol. Med. 106, 555.

Kirchner, J. G. (1967). In 7echnique of Organic Chemistry, vol. 8, p. 607 [A. W. Weissberger, editor]. New York: Interscience.

Kritchevsky, D. \& Story, J. A. (1974). J. Nutr. I04, 458.

Kuksis, A. (197I). In Bile Acids, p. 204 [P. P. Nair and D. Kritchevsky, editors]. New York: Plenum Press.

Maizel, J. V., Bunkardt, H. J. \& Mitchell, H. K. (1964). Biochemistry, Easton, 3, 424.

Malinkow, M. R., McLaughlin, P., Kohler, G. O. \& Livingston, A. L. (1977). Steroids 29, 105.

Mathur, K. S., Khan, M. A. \& Sharma, R. D. (I968), Br. Med. J. i, 30.

Mikhailova, I. Y., Nikolova, M. P. \& Stoyanov, D. P. (1965). Chem. Abstr. 64, 11735 b.

Moore, J. H. (1967). Br. J. Nutr. 21, 207.

Morris, R. J., Dye, W. B., \& Gisler, P. S. (196r). J. org. Chem. 30, 166.

Newman, H. A. I., Kummerow, F. A. \& Scott, H. A. (1958). J. Poult. Sci. 37, 42.

Oakenfull, D. \& Fenwick, D. E. (1977). Aust. J. Chem. 30; 335.

O'Dell, B. L., Regam, W. O. \& Beach, T. J. (I959). Miss. Univ. Agric. Expt. Sta. Res. Bull. $702,12$.

Ponec, V., Knor, Z. \& Cerny, S. (1974). Adsorption on Solids, pp. 596-607. London: Butterworths.

Riccardi, B. A. \& Fahrenbach, M. J. (1969). Proc. Soc. exp. Biol. Med. 124, 749.

Robinson, R. A. \& Stokes, R. H. (1955). Electrolyte Solutions, pp. 113-127. London: Butterworths.

Shedlovsky, T. (I 949). In Physical Methods of Organic Chemistry, vol. I, p. I65I [A. Weissberger, editor]. New York: Interscience.

Sirtori, C. R., Agradi, E., Conti, F., Mantero, O. \& Gatti, E. (1977). Lancet i, 275.

Smith, A. K. \& Circle, S. J. (1972). Soybeans: Chemistry and Technology, vol. 1, Westport: Avi Publishing Co.

Smith, M. B., Reynolds, T. M., Buckingham, C. P. \& Back, J. F. (I974). Aust. J. Biol. Sci. $27,349$.

Story, J. A. \& Kritchevsky, D. (1976). J. Nutr. 106, 1292.

Trowell, H. C. (1972). Atherosclerosis 16, 318.

Trowell, H. C. (1975). In Refined Carbohydrate Foods and Disease, pp. 195-226 [D. P. Burkitt and H. C. Trowell, editors]. London: Academic Press.

Truswell, A. S. \& Kay, R. M. (1976). Lancet i, 367.

Van Soest, P. J. (1963). J. Ass. off. agric. Chem. 46, 825.

Varshney, I. P. (1966). Indian J. Chem. 7, 446.

Yoka, N. \& Iseda, S. (1965). Chem. Abstr. 62, 16359. 